\title{
8
}

\section{The transformation and upgrading of processing trade and its impact on firms' productivity}

\author{
Kunwang Li and Haoran $\mathrm{Hu}$
}

\section{Introduction}

Since the beginning of the reform and opening-up period, China's foreign trade has become one of the important drivers of economic growth. The proportion of exports in total gross domestic product (GDP) increased from less than 4 per cent in the initial period of opening up to its highest value, of 34.5 per cent, in 2007. China's export growth has been largely related to the rapid development of processing trade. Before the Global Financial Crisis (GFC), processing trade accounted for more than 50 per cent of China's exports. Processing trade has made great contributions to employment, industrialisation and foreign trade in China.

The processing trade policy was introduced in the late 1970s in China. Processing trade refers to the business activity of importing all or part of the raw materials, auxiliary materials, parts and components, accessories and packaging materials from abroad in bond and re-exporting the finished products after processing or assembly by enterprises within the mainland. China's processing trade is divided into two categories: processing with supplied materials and processing with imported materials. When processing with supplied materials, the imported materials and parts are supplied by foreign parties, who are also responsible for selling the finished products. The enterprises processing with supplied materials do not have to make foreign exchange payments for the imports and only charge the 
foreign party a processing fee. Under processing trade with imported materials, the enterprises make foreign exchange payments for those imported materials and parts and export the finished products after processing.

China's processing trade has developed in the context of economic globalisation and the deepening international division of labour, relying on factors such as low land and labour costs, and facilitated by international industrial transfers. However, China's processing trade has also faced problems-for instance, many processing trade enterprises remain at the low end of the global value chain, with lagging technology and low research and development $(\mathrm{R} \& \mathrm{D})$ capabilities, and many are implicated in causing serious harm to the environment. As the costs of labour, land and resources grow and environmental pressures increase, China's processing trade faces more and more challenges.

Starting in 2003, China introduced a series of policies aimed at promoting the transformation and upgrading of processing trade. Primary examples of these measures include:

1. Attracting foreign direct investment in more advanced technology and greater value-added content in processing trade and encouraging multinational companies to transfer their R\&D centres to China.

2. Adjusting the processing trade product catalogue of prohibited categories seven times between 2003 and 2005 to include 1,803 products, with the aim of optimising the structure of processing trade.

3. Encouraging labour-intensive processing enterprises in the eastern region to develop in the central and western regions, and successfully establishing 44 processing trade transfer bases in underdeveloped regions in China since 2006.

4. Reducing or abolishing export tax rebates for products related to energyintensive, high-pollution and resource-based industries.

5. Establishing the national demonstration zone for the transformation and upgrading of processing trade in the Pearl River Delta and Suzhou Industrial Park in 2010.

The overall goal of these policies is to promote the adjustment of processing trade from low technology and low value added to high technology and high value added, and to lead the upgrading of domestic technology and economic development.

Figure 8.1 shows that, before 2006, the trends for processing trade and ordinary trade were basically the same, but after 2007 , the proportion of processing trade in total exports began to decline sharply. The proportion of processing trade exports in 2004 was 55.3 per cent and was much the same the following year. The slight decline 
witnessed in 2006 was related to the Ministry of Commerce's significant adjustment of the export product catalogue for processing trade in 2005. Beginning in 2011, the proportion of processing trade was exceeded by that of ordinary trade.

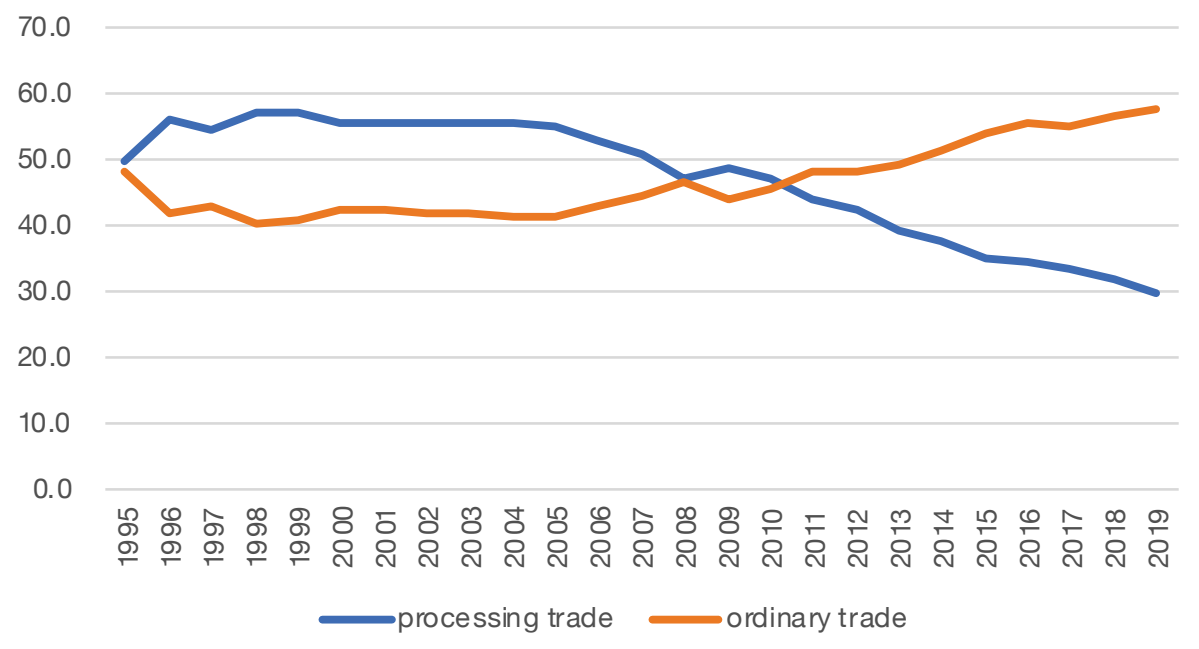

Figure 8.1 Proportions of processing trade and ordinary trade in total exports

Source: Chinese Monthly Customs Transactions, General Administration of Customs of China.

The strategy of transforming and upgrading processing trade involves the adjustment of business entities, product catalogues and production chains. At the microlevel, the impact of policies on processing trade enterprises takes effect through three main channels: first, enterprises shift from processing to ordinary trade or no longer engage in export; second, firms continue to engage in processing trade, but their product categories shift to products with higher technological content or higher value added; and third, processing trade enterprises move their processing bases from the coast to inland regions. The evaluation of industrial policy needs to look at its impact on resource allocation. Based on the theory of heterogeneous firms' trade, if a firm's average productivity increases after a policy is implemented, the policy improves the efficiency of resource allocation; otherwise, it leads to resource misallocation.

This chapter aims to investigate the impact of processing trade transformation and upgrading policies on China's resource allocation. We use Chinese customs and industrial panel data to empirically test the impact of these policies on enterprise productivity by using the double-difference method.

The rest of the chapter is arranged as follows: section two describes the data sources, section three is the econometric specification of the evaluating policy, section four is the empirical test and the final section provides concluding remarks. 


\section{Data and sources}

The data used in this study are drawn from two large panel datasets of Chinese manufacturing firms. The first is the Chinese Monthly Customs Transactions from 2002 to 2006, which contain the value and quantity of all Chinese trade transactions at the six-digit product level. We supplement the trade data with information on manufacturing firms from the Annual Survey of Manufacturing-an extensive survey of Chinese manufacturing firms conducted each year by the National Bureau of Statistics of China (NBS). We merge the two datasets to create a sample set with 204,968 observations, accounting for 27.7 per cent of the customs database and 13.1 per cent of the manufacturing database. The customs database was constructed beginning in 2000, which is later than the manufacturing database. We therefore set the start of our empirical study as the year 2000 and opted to use 2000-06 as our research period. After 2007, a lot of blanks exist in the 'trade mode' column in the customs database and the label of 'ordinary trade' is missing. However, manual checking finds that these blanks are not equivalent to 'ordinary trade'. From another perspective, Chinese exports began to decline in February 2007, affected by the US subprime mortgage crisis, with processing trade exports declining even more rapidly. Therefore, the subprime mortgage crisis, together with the RMB4 trillion economic stimulus plan enacted in 2008 and the resulting European debt crisis, can generate an ambiguous effect on those corresponding observations.

\section{Chinese Monthly Customs Transactions database}

The customs database contains the product-level transaction data provided by the General Administration of Customs. It records all transaction data for import and export firms on a monthly basis, and we add up this data to obtain an annual value. Observed variables include firm name, telephone number, postal code, dollardenominated import and export values, eight-digit Harmonised System (HS) code of imported and exported products, export destination, transportation method, trade mode and firm status. We use customs data to identify firms' trading patterns and status. Trade patterns include ordinary trade, processing trade and other trade modes. We classify firms marked as 'ordinary trade' as ordinary trade firms and classify firms labelled 'processing trade with imported materials' or 'processing trade with supplied materials' as processing trade firms. Together these two groups of firms account for about 98 per cent of the country's total exports. There is a deviation in the above classifications: since some firms are engaged in both ordinary trade and processing trade, we classify them as mixed-pattern firms. To eliminate the problem of sample selection bias, we will group the mixed-pattern firms according to the proportion of their processing trade export participation. We then incorporate them into the treatment and control groups as needed. 
To get a direct measure of firms' productivity, more firm-level information is needed. The manufacturing database contains such information as firms' financial status, industry and region. To merge the customs and manufacturing databases, we follow the method of Tian and $\mathrm{Yu}$ (2012). First, we directly match the company name; then we conduct a second matching process for data that remain unmatched in the customs database. Both the customs database and the manufacturing database contain information on phone numbers and postal codes. We use the last seven digits of the phone numbers and the postal codes as related information to identify the same firm in the two databases.

\section{Annual Survey of Manufacturing database}

The observations of the manufacturing database can be refined to the county level with four-digit industries. We follow the method from existing research to process these observations (Brandt et al. 2012; Nie et al. 2012). The industry coding standard has changed over the course of our sample period: before 2002, the manufacturing database used the national economic industry classification (GB/T4754-1994); during the period 2003-06, the classification standard changed to GB/T4754-2002. To keep the industry code consistent, we unify the classification standard into the national economic industry classification (GB/T4754-2002). For the verification of area codes, we reconfirm the area codes according to the administrative division codes published on the website of the NBS. We delete observations with missing records for assets, value added and net value of fixed assets. We also delete observations that do not comply with accounting rules, dropping firms with total assets less than current assets, total assets less than net fixed assets or accumulated depreciation less than current depreciation. Firms with fewer than eight employees are also excluded.

The manufacturing database includes indicators such as a firm's output value, fixed assets and number of employees, which facilitate the calculation of total factor productivity (TFP). Currently, the mainstream econometric method for identifying the TFP value is Olley-Pakes' (1996) semiparametric estimation method (referred to as the OP method) and Levinsohn-Petrin's (2003) estimation method (referred to as the LP method). The Solow residual value is prone to endogeneity problems and sample selection bias, while the use of the OP and LP methods can solve these problems. This chapter uses the OP method as the basic regression method to construct a TFP index (TFP_OP), while using the LP method for mutual robustness tests. The data needed for calculating TFP are all from the manufacturing database.

\section{Empirical model specification}

When estimating the effect generated by a certain type of industrial policy, problems can potentially include: 1) the direct policy measure cannot be identified by constructing indexes as a regressor; 2) other exogenous shocks simultaneously 
involved in the phenomenon may be attenuated in our estimation methodology; and 3) it is critical to be able to specify the parallel trends in the pretreatment periods. To clarify these issues, we opted to use a difference-in-difference regression method, through which we are able to separate the observations into treatment and control groups. By introducing time dummy variables, we are able to control for pretreatment parallel trends. Given that policies aimed at the transformation and upgrading of processing trade were launched in 2003, we chose that year as the starting point for the treatment.

We argue that firms primarily involved in the export sector behave differently from those in non-export sectors. Export firms are affected by tariffs and other foreign trade policies, while non-export firms' product markets are not affected by these fluctuations. Foreign-invested firms and joint ventures undertake 85 per cent of processing trade in China (Lu et al. 2010). Previous studies have found that Chinese non-export firms tend to be more efficient than export companies (Dai et al. 2014). Therefore, we exclude non-exporting companies from our sample dataset. We chose to use firms primarily engaged in ordinary trade as a control group, leaving other firms primarily engaged in processing trade clustered in the treatment group. We then show the annual average TFP trend of the two groups of firms. From Figure 8.2, it can be seen that the assumption of parallel trends is met and there is little difference in the average annual productivity of the two groups before 2003, whereas after 2003, the productivity of processing trade firms declines markedly. We have conducted a parallel trend hypothesis test below, and the results are shown in Table 8.2.

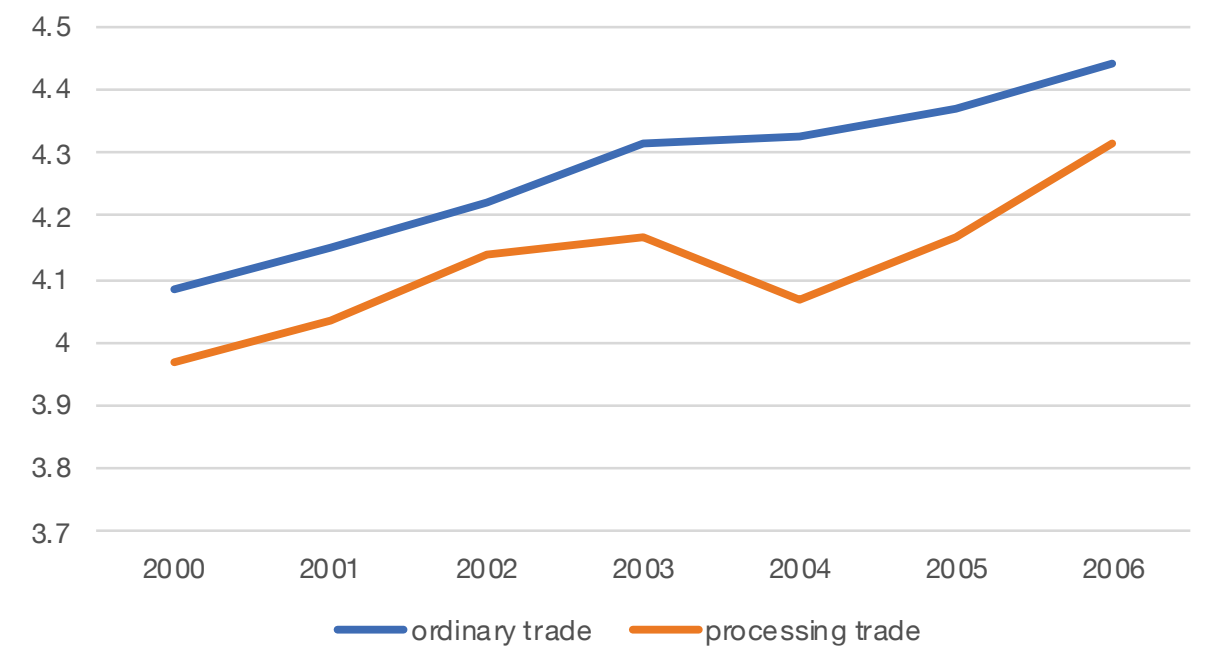

Figure 8.2 Productivity growth trend of different types of exporters: Processing trade versus ordinary trade (per cent)

Source: Annual Survey of Manufacturing, National Bureau of Statistics of China. 
We use a fixed-effect regression model that controls for firm location, sector and time. The econometric model can be expressed as follows: the subscripts $t, j, i$ and $r$ represent year, firm, two-digit industry and location, respectively; $\mathrm{X}$ is the control variable; $\varepsilon_{t j}$ is the error term. The dummy variable treat indicates whether the observation is affected by the policy. We use treat=1 to indicate the treatment group and treat $=0$ to indicate the control group unaffected by the policy. The term time represents the time dummy variable, indicating a period during which the policy has been implemented. After the policy is implemented, we have time $=1$, otherwise the dummy variable takes on the value of zero. The term treat $\times$ time represents the interaction effect of our treatment and time, representing the net effect before and after the policy is implemented. In the empirical section below, we use $t t$ to represent the interaction term. To eliminate interference from other factors in the model, we introduce control variables at the firm, city, province and industry levels.

\section{Equation 8.1}

$$
T F P_{t j}=a_{r}+a_{i}+a_{t}+\beta \text { treat }_{t j} \times \text { time }_{t j}+\sum_{n} \gamma_{n} X_{n t j}+\varepsilon_{t j}
$$

In the benchmark regression model, we first add the control variables at the firm level and then gradually add the control variables at the city, province and industry level. Corporate capital intensity (capint) is calculated by dividing the annual average of net fixed assets by the annual average of all employees. We then take the logarithm value and deflate it using the fixed-asset price index based on the year 2000. The age of a firm is measured by the period the firm has actually existed, which we calculate by taking the logarithm of the difference between the current year and the year the firm was established. Wage payment ability (wage) is measured by taking the logarithm of the ratio of the firm's payable employee compensation to the annual average of all employees. Production capacity (output) is measured by taking the logarithm of the total industrial output per capita at constant prices. We then deflate the value using the industrial producer price index based on the year 2000. The scale of a firm is measured by the logarithm of the number of its employees. The level of firm profitability (prorate) is measured by the logarithm of total profit per capita, converting it using the industrial producer price index based on the year 2000 . We identify the status of the firm via the sixth digit in the 10-digit customs enterprise code, classifying numbers ' 4 ' and ' 9 ' as foreign-funded firms and ' 2 ' and ' 3 ' as Chinese-foreign firms and Chinese-foreign joint ventures. The dummy variable (foe) is set for foreign-funded background firms, which takes the value of 1 when firms are foreign-funded or joint ventures and 0 otherwise. State-owned firms and collective firms are represented by the numbers ' 1 ' and ' 5 ', respectively. We set the dummy variable (soe), which takes the value of 1 for state-owned and collective firms. Private firms and individual businesses are represented by the numbers ' 6 ', ' 7 ' and ' 8 ' and we classify these observations as private enterprises. The technological intensity of export products differs in many ways, and we employ the classification method proposed by Lall, Weiss and Zhang (2006) to ascertain the level of technological 
intensity for each product from each company. We assign the technological level of a firm according to the technological intensity of its product with the largest export proportion. We then set the high technology-intensity dummy variable as htech, which takes the value of 1 for firms with high technology intensity. Similarly, the term mtech is for firms with a medium level of technological intensity.

In the following robustness test, to eliminate the interference of variance at the regional and industrial economic development levels, we introduce control variables at the city, province and industry level. The regional income level (lnwage) is measured by the per capita wage of the prefecture-level city, which is deflated by the consumer price index. Regional capital intensity (pcap) is measured by the per capita fixed assets of prefecture-level cities. The regional development level (pgdp) is measured by the per capita GDP of the prefecture-level city. We take the logarithm value and deflate it using the GDP deflator. Regional traffic conditions (pky) are measured by the ratio of the number of passengers transported in prefecture-level cities to the permanent population of the region. The degree of marketisation of each province (market) is measured by the comprehensive index of the marketisation process of each province proposed by Fan et al. (2011). The economic agglomeration degree (ecoag) of each province is constructed based on the method of Shi and Zhang (2016), which is measured according to the ratio of each province's GDP to its geographic area. The industrial structure (FGP) is measured by the proportion of agricultural output value in the total regional output value in the same city. Industry concentration (HHI) is used to reflect the degree of competition in industry $i, H H I_{i}=\Sigma_{j}\left(y_{i}^{j}\right)^{2}$, where $y_{i}^{j}$ represents the proportion of the employed population of firm $j$ in industry $i$. Here industry is defined at the two-digit level. The degree of industrial agglomeration (IDSAG) is constructed based on the method proposed by Ellison and Glaeser (1999), mainly taking into account differences in the composition of firms in the industry, with some industries constituted by large-scale firms and others by a large number of small firms. The corresponding subscripts are as follows: $r$ refers to the city; refers to the proportion of employment in city $r$ in the total employment in the country; refers to the proportion of the employment in city $i$ in the total employment in industry $i$ in the country. And the measure is similar to the former constructed industrial concentration measure. However, here we select industries at the four-digit level.

\section{Equation 8.2}

$I D S A G_{i}=\frac{\sum_{r}\left(x_{r}-s_{r}^{i}\right)^{2}-\left[1-\sum_{r}\left(x_{r}\right)^{2}\right] H_{i}}{\left[1-\sum_{r}\left(x_{r}\right)^{2}\right]\left(1-H_{i}\right)}$ 


\section{Results}

\section{Primary results}

Since the random-effect model-fitting approach was rejected by the Hausman test, we choose the fixed-effect model in this study. In the benchmark model specification, the TFP heterogeneity mainly relies on across-firm differences in export patterns, controlling for firm location, sector and time effects. As the regression result displays, the interaction term coefficient is negative and statistically significant at the 1 per cent level. Since the export pattern choice could hinge on substantial firm heterogeneity, we cluster samples via the propensity score matching (PSM) method. The reported results in columns (5) and (6) are the regression model using the matched samples. Furthermore, the difference-in-difference (DID) method is proven to be robust across different sample sets.

As shown in Table 8.1, we find a negative effect on firms' TFP value caused by processing trade transformation and upgrading policies. Former research results shed light on the causal role of processing trade in the learning-by-exporting effect (Ge 1999), especially for those countries with firms primarily engaged in processing trade (Kandogan 2003). Previous research has also focused on the economic growth linked to this learning effect (Feenstra and Hanson 1995). On the other hand, in addition to potential positive prompting effects, these transformation and upgrading policies may exert a crowding-out effect in the short term (Shang and Zhu 2017), thereby increasing the costs of operating in the market. In the course of economic development, the industrial structure is constantly changing (Gan et al. 2011); to meet regulatory requirements, firms need to adjust their production strategies or introduce new production processes, which might in turn attenuate their original innovation intensity, restrict their innovation capabilities or reduce their profit margin and productivity (Blonigen 2016).

Table 8.1 Benchmark model regression

\begin{tabular}{|l|c|c|c|c|c|c|}
\hline \multirow{2}{*}{ Variable } & $\mathbf{( 1 )}$ & $\mathbf{( 2 )}$ & $\mathbf{( 3 )}$ & $\mathbf{( 4 )}$ & $\mathbf{( 5 )}$ & $\mathbf{( 6 )}$ \\
\cline { 2 - 7 } & TFP_OP & TFP_OP & TFP_LP & TFP_LP & TFP_OP & TFP_LP \\
\hline \multirow{3}{*}{$t t$} & $-0.1260^{\star \star \star}$ & $-0.1390^{\star \star \star}$ & $-0.1180^{\star \star \star}$ & $-0.1290^{\star \star \star}$ & $-0.1730^{\star \star \star}$ & $-0.1320^{\star \star \star}$ \\
\cline { 2 - 7 } & $(0.0107)$ & $(0.0133)$ & $(0.0107)$ & $(0.0133)$ & $(0.0174)$ & $(0.0171)$ \\
\hline \multirow{3}{*}{ wage } & $0.3700^{\star \star \star}$ & $0.3800^{\star \star \star}$ & $0.4050^{\star \star \star}$ & $0.4210^{\star \star \star}$ & $0.4260^{\star \star \star}$ & $0.4490^{\star \star \star}$ \\
\cline { 2 - 7 } & $(0.0042)$ & $(0.0075)$ & $(0.0042)$ & $(0.0076)$ & $(0.0124)$ & $(0.0124)$ \\
\hline \multirow{2}{*}{ gge } & $0.0780^{\star \star \star}$ & $0.0590^{\star \star \star}$ & $0.0310^{\star \star \star}$ & $0.0130^{\star \star \star}$ & $0.0650^{\star \star \star}$ & $0.0120^{\star}$ \\
\cline { 2 - 7 } & $(0.0041)$ & $(0.0044)$ & $(0.0041)$ & $(0.0044)$ & $(0.0068)$ & $(0.0067)$ \\
\hline \multirow{2}{*}{ scale } & $0.0370^{\star \star \star}$ & $0.0460^{\star \star \star}$ & $0.4760^{\star \star \star}$ & $0.4850^{\star \star \star}$ & $0.0720^{\star \star \star}$ & $0.5200^{\star \star \star}$ \\
\cline { 2 - 7 } & $(0.0030)$ & $(0.0051)$ & $(0.0030)$ & $(0.0051)$ & $(0.0069)$ & $(0.0070)$ \\
\hline
\end{tabular}




\begin{tabular}{|c|c|c|c|c|c|c|}
\hline \multirow{2}{*}{ Variable } & (1) & (2) & (3) & (4) & (5) & (6) \\
\hline & TFP_OP & TFP_OP & TFP_LP & TFP_LP & TFP_OP & TFP_LP \\
\hline \multirow[t]{2}{*}{ capint } & $0.0140^{\star \star \star}$ & $-0.0140^{\star \star \star}$ & $0.0680^{\star \star \star}$ & $0.0420^{\star \star \star}$ & 0.0070 & $0.0710^{\star \star \star}$ \\
\hline & $(0.0023)$ & $(0.0035)$ & $(0.0023)$ & $(0.0035)$ & $(0.0053)$ & $(0.0052)$ \\
\hline \multirow[t]{2}{*}{ output } & $0.0000^{\star \star \star}$ & $0.0000^{\star \star \star}$ & $0.0000^{\star \star *}$ & $0.0000^{\star \star \star}$ & $0.0000^{\star \star \star}$ & $0.0000^{\star \star \star}$ \\
\hline & $(0.0000)$ & $(0.0000)$ & $(0.0000)$ & (0.0000) & $(0.0000)$ & $(0.0000)$ \\
\hline \multirow[t]{2}{*}{ prorate } & $0.8530^{\star \star \star}$ & $0.8470^{\star \star \star}$ & $0.8520^{\star \star \star}$ & $0.8470^{\star \star \star}$ & $0.6700^{\star * \star}$ & $0.6680^{\star \star \star *}$ \\
\hline & $(0.0117)$ & $(0.2018)$ & $(0.0117)$ & $(0.2025)$ & $(0.2329)$ & $(0.2399)$ \\
\hline \multirow[t]{2}{*}{ htech } & $0.1160^{\star \star \star}$ & $0.0440^{\star \star \star}$ & \multirow{2}{*}{$\begin{array}{l}0.1120^{\star \star \star} \\
(0.0083)\end{array}$} & \multirow{2}{*}{$\begin{array}{c}0.0430^{\star \star \star} \\
(0.0109)\end{array}$} & $0.0350^{\star *}$ & $0.0530^{\star \star \star}$ \\
\hline & (0.0083) & $(0.0109)$ & & & $(0.0162)$ & $(0.0160)$ \\
\hline \multirow[t]{2}{*}{ mtech } & 0.0080 & $0.0150^{\star}$ & 0.0030 & $0.0150^{*}$ & 0.0050 & $0.0240^{*}$ \\
\hline & $(0.0070)$ & $(0.0080)$ & $(0.0070)$ & $(0.0080)$ & (0.0129) & (0.0129) \\
\hline \multirow[t]{2}{*}{ foe } & 0.0100 & $0.0240^{\star \star \star}$ & -0.0030 & 0.0090 & 0.0180 & -0.0120 \\
\hline & $(0.0079)$ & (0.0079) & (0.0079) & $(0.0079)$ & $(0.0128)$ & $(0.0125)$ \\
\hline \multirow[t]{2}{*}{ soe } & -0.0020 & $-0.0400^{\star * *}$ & 0.0050 & $-0.0420^{* * *}$ & $-0.0820^{\star * *}$ & $-0.1080^{\star * *}$ \\
\hline & $(0.0115)$ & $(0.0124)$ & $(0.0115)$ & $(0.0124)$ & (0.0178) & $(0.0177)$ \\
\hline \multirow[t]{2}{*}{ cons } & $2.8100^{\star \star \star}$ & $3.0370^{\star \star \star}$ & $2.7720^{\star \star \star}$ & $2.9590^{\star \star \star}$ & $1.7640^{\star \star \star}$ & $1.8600^{\star \star \star}$ \\
\hline & $(0.0212)$ & $(0.2587)$ & $(0.0212)$ & $(0.2586)$ & $(0.3406)$ & $(0.3342)$ \\
\hline $\begin{array}{l}\text { City fixed } \\
\text { effects }\end{array}$ & - & Yes & - & Yes & Yes & Yes \\
\hline $\begin{array}{l}\text { Industry } \\
\text { fixed effects }\end{array}$ & - & Yes & - & Yes & Yes & Yes \\
\hline $\begin{array}{l}\text { Year fixed } \\
\text { effects }\end{array}$ & - & Yes & - & Yes & Yes & Yes \\
\hline Observations & 135,264 & 135,264 & 135,002 & 135,002 & 53,088 & 53,020 \\
\hline
\end{tabular}

Notes: Standard errors in parentheses; model (1) and model (3) are random-effect regression models.

Source: Authors' own estimation.

\section{Parallel trend and robustness tests}

We follow Alder et al.'s (2016) method to perform a parallel trend test, which consists of adding a year dummy variable (year_dum) for each year to the model. For example, for 2003, we let the corresponding dummy variable take the value of 1 with other observations taking the value of zero. In addition, we add the interaction term (treat $\times$ year_dum) for the identification of the effect generated by the time dummy variable (year_dum) and the policy dummy variable (treat) jointly. In the empirical part, $t$ year is used instead of treatxyear_dum. For example, in 2003, it is expressed as t_2003. As shown in Equation 8.3, the regression results are displayed in Table 8.2. 


\section{Equation 8.3}

$$
\begin{aligned}
\text { TFP }_{t j}=a_{r}+ & a_{i}+a_{t}+\beta \text { treat }_{t j} \times \text { time }_{t j}+\sum_{n} \lambda_{n} \text { year_dum } \\
& +\sum_{n} \mu_{n} \text { treat }_{t j} \times \text { year_dum } \\
t j & +\sum_{n} \gamma_{n} X_{n t j}+\varepsilon_{t j}
\end{aligned}
$$

It can be seen that the interaction term coefficients from 2000 to 2002 are not statistically significant, but become significantly negative after 2003, showing that the test of the parallel trend hypothesis has been passed.

\begin{tabular}{|c|c|c|}
\hline \multirow{2}{*}{ Variable } & (1) & (2) \\
\hline & TFP_OP & TFP_LP \\
\hline \multirow[t]{2}{*}{$t \_2000$} & -0.0440 & -0.0580 \\
\hline & $(0.0346)$ & (0.0353) \\
\hline \multirow[t]{2}{*}{$t \_2001$} & -0.0320 & -0.0380 \\
\hline & (0.0251) & (0.0256) \\
\hline \multirow[t]{2}{*}{$t \_2002$} & 0.0190 & 0.0140 \\
\hline & $(0.0414)$ & $(0.0414)$ \\
\hline \multirow[t]{2}{*}{$t+2003$} & $-0.1150^{\star \star \star}$ & $-0.1040^{\star \star \star}$ \\
\hline & (0.0296) & (0.0282) \\
\hline \multirow[t]{2}{*}{$t \_2004$} & $-0.2150^{\star \star \star}$ & $-0.2070^{\star * *}$ \\
\hline & $(0.0277)$ & $(0.0274)$ \\
\hline \multirow[t]{2}{*}{$t \_2005$} & $-0.1580^{\star \star \star}$ & $-0.1590^{\star * *}$ \\
\hline & $(0.0280)$ & $(0.0270)$ \\
\hline \multirow[t]{2}{*}{$t \_2006$} & $-0.1340^{\star \star \star}$ & $-0.1440^{\star \star \star}$ \\
\hline & (0.0333) & $(0.0337)$ \\
\hline Observations & 135,264 & 135,002 \\
\hline
\end{tabular}

\section{Table 8.2 Parallel trend test}

*** $\mathrm{p}<0.01$

** $\mathrm{p}<0.05$

${ }^{*} p<0.1$

Source: Authors' own estimation.

A sample selection bias may lie in the benchmark model, primarily caused by the fact that the sample of mixed-pattern firms is not considered. Mixed-pattern firms could engage in both ordinary trade and processing trade, and such firms are more or less affected by the policy. Hence it is difficult to identify the precise impact of the policy. We cluster different proportions of processing trade among the mixed-pattern firms, with firms with proportions above three-quarters used as the treatment group and those with proportions below one-quarter used as the control group. The results are displayed in Table 8.3. Models (1) and (2) only include mixed-pattern firms and we perform the regression according to the above grouping principle. The regression results show 
that, although the interaction term coefficient is negative, it does not pass the test for significance. Models (3) and (4) are placebo tests. We use samples between the threequarters and the median of the mixed-pattern firm as the treatment group, and the onequarter to the median as the control group. We can see that the regression results are not significant. Models (5) and (6) merge all mixed-pattern firms into the treatment group and the control group, and the regression results are consistent with the basic model. On the whole, it appears that adding a sample of mixed-pattern firms may interfere with the accurate assessment of policy effectiveness. In this section, we use the sample of mixed firms to perform a robustness test. The following estimation mainly makes use of samples of purely processing trade and purely ordinary trade enterprises.

Table 8.3 Regression with mixed-pattern firms

\begin{tabular}{|l|c|c|c|c|c|c|}
\hline \multirow{2}{*}{ Variable } & $(\mathbf{1})$ & $\mathbf{( 2 )}$ & $\mathbf{( 3 )}$ & $\mathbf{( 4 )}$ & $\mathbf{( 5 )}$ & $\mathbf{( 6 )}$ \\
\cline { 2 - 7 } & TFP_OP & TFP_LP & TFP_OP & TFP_LP & TFP_OP & TFP_LP \\
\hline \multirow{2}{*}{$t$} & -0.0570 & -0.1200 & 0.1800 & 0.1840 & $-0.0730^{\star \star \star}$ & $-0.0680^{\star \star \star}$ \\
\cline { 2 - 7 } & $(0.1268)$ & $(0.1276)$ & $(0.1724)$ & $(0.1769)$ & $(0.0086)$ & $(0.0087)$ \\
\hline Observations & 29,750 & 29,709 & 35,396 & 35,351 & 200,410 & 200,062 \\
\hline
\end{tabular}

${ }^{\star * *} p<0.01$

** $\mathrm{p}<0.05$

${ }^{*} p<0.1$

Notes: Regression equations include control variables regarding firms. City, industry and time fixed effects have been controlled for unobserved variation.

Source: Authors' own estimation.

We controlled for firm-level characteristic variables as well as the fixed effects of city and industry, as well as adopting the PSM method to attenuate the endogeneity bias. However, there may be deviations in policy results caused by variances in regional and industrial development trends and we therefore need to further eliminate endogeneity problems caused by the pretreatment trends of regional and industrial development. To do this, we added regional-level and industry-level variables into the model to ensure the exogeneity of the policy. At the same time, we performed PSM on the variables of firm, region and industry to select more similar samples. Among them, the region and industry-level characteristics are controlled by newly added variables. The regression results are shown in Table 8.4. It can be seen that the interaction term coefficient is statistically significantly negative-consistent with the benchmark model. The control variables at the regional level are also statistically significant. Factors such as regional wage levels, economic development levels, capital density and economic accumulation are positively correlated with the production efficiency of firms, which is consistent with economic facts. At the same time, the control variables at the industry level vary in the opposite direction to productivity, which is consistent with the empirical fact that agricultural productivity is lower than that of manufacturing or service industries. By collecting observations from our dataset, we can identify the economic zone attributes of each city from the fifth digit of the customs code. For example, ' 4 ' 
and ' 5 ' represent the bonded area and export processing zone, respectively. ${ }^{1}$ Each city corresponds to only one economy zone code, which shows that the distribution of firms may differ across cities. Therefore, on the basis of controlling the fixed effects of cities and industries, we further add all control variables at the city, province and industry level to ensure the exogeneity of policies.

Table 8.4 Robustness test for region and industry characteristics

\begin{tabular}{|c|c|c|c|c|c|c|c|c|}
\hline \multirow{3}{*}{ Variable } & (1) & (2) & (3) & (4) & (5) & (6) & (7) & (8) \\
\hline & TFP_OP & TFP_LP & TFP_OP & TFP_LP & TFP_OP & TFP_LP & TFP_OP & TFP_LP \\
\hline & \multicolumn{2}{|c|}{ region } & \multicolumn{2}{|c|}{ industry } & \multicolumn{2}{|c|}{ Regional PSM } & \multicolumn{2}{|c|}{ Industrial PSM } \\
\hline \multirow[t]{2}{*}{$t t$} & $-0.1170^{\star \star \star}$ & $-0.1040^{\star \star \star}$ & $-0.1390^{\star \star \star}$ & $-0.1290^{\star \star \star}$ & $-0.1110^{\star \star \star}$ & $-0.1080^{\star \star \star}$ & $-0.1490^{\star \star \star}$ & $-0.1470^{\star \star \star}$ \\
\hline & $(0.0140)$ & $(0.0141)$ & $(0.0133)$ & $(0.0133)$ & $(0.0204)$ & $(0.0206)$ & $(0.0189)$ & $(0.0181)$ \\
\hline \multirow[t]{2}{*}{ Inwage } & $0.0430^{\star \star \star}$ & $0.0460^{\star \star \star}$ & & & $0.0710^{*}$ & $0.0820^{\star \star}$ & & \\
\hline & (0.0146) & $(0.0147)$ & & & (0.0366) & $(0.0387)$ & & \\
\hline \multirow[t]{2}{*}{$p g d p$} & -0.0190 & -0.0260 & & & 0.0430 & $0.0520^{\star}$ & & \\
\hline & (0.0173) & (0.0173) & & & (0.0281) & (0.0282) & & \\
\hline \multirow[t]{2}{*}{ рсар } & $0.0510^{\star \star \star}$ & $0.0560^{\star \star \star}$ & & & $0.0310^{\star}$ & $0.0390^{\star \star}$ & & \\
\hline & (0.0114) & (0.0114) & & & (0.0189) & (0.0194) & & \\
\hline \multirow[t]{2}{*}{ pky } & 0.0060 & 0.0050 & & & $-0.0380^{\star}$ & $-0.0540^{\star \star}$ & & \\
\hline & (0.0118) & (0.0118) & & & (0.0222) & (0.0225) & & \\
\hline \multirow[t]{2}{*}{ market } & 0.0110 & 0.0130 & & & $0.0470^{\star \star \star}$ & 0.0220 & & \\
\hline & (0.0079) & (0.0079) & & & (0.0168) & (0.0173) & & \\
\hline \multirow[t]{2}{*}{ ecoag } & $0.1450^{\star \star \star}$ & $0.1500^{\star \star \star}$ & & & $0.1870^{\star \star \star}$ & $0.1740^{\star \star \star}$ & & \\
\hline & (0.0336) & $(0.0335)$ & & & $(0.0641)$ & $(0.0656)$ & & \\
\hline \multirow[t]{2}{*}{ FGP } & & & $-0.0030^{\star \star \star}$ & $-0.0040^{\star \star \star}$ & & & $-0.0070^{\star \star \star}$ & $-0.0080^{\star \star \star}$ \\
\hline & & & $(0.0011)$ & $(0.0011)$ & & & (0.0022) & $(0.0023)$ \\
\hline \multirow[t]{2}{*}{ IDSAG } & & & -0.0600 & -0.1610 & & & -0.0260 & -0.0690 \\
\hline & & & $(0.3047)$ & $(0.3137)$ & & & $(0.3411)$ & $(0.3451)$ \\
\hline \multirow[t]{2}{*}{$\mathrm{HHI}$} & & & 0.0830 & 0.0440 & & & 1.0530 & 0.5310 \\
\hline & & & $(0.2726)$ & $(0.2781)$ & & & (0.6569) & $(0.5516)$ \\
\hline Observations & 135,169 & 134,907 & 135,264 & 135,002 & 46,120 & 46,081 & 50,757 & 50,828 \\
\hline
\end{tabular}

*** $p<0.01$

** $\mathrm{p}<0.05$

${ }^{*} p<0.1$

Notes: Regression equations include control variables regarding firms. City, industry and time fixed effects have been controlled for unobserved variation.

Source: Authors' own estimation.

1 Among them, ' 1 ' stands for special economic zones; ' 2 ' is economic and technological development zones; ' 3 ' high-tech development zones; '4' bonded areas; '5' export processing zones; and '9' other unlisted areas. For the policies and regulations prohibiting ordinary trade, please refer to the Interim Measures of the Customs of the People's Republic of China on the Supervision of Export Processing Zones (The State Council of the People's Republic of China 2000). 
The productivity of the treatment group and control group firms should have the same pretreatment trends. To eliminate the potential impact of different pretreatment trends, we add a time trend term for control (Jayachandran et al. 2010). Specifically, we add the corresponding year $(t)$ to models (1) and (2) in Table 8.5. We take the logarithm to process it. We also add the interaction term (ts) to combine the year $(t)$ with the policy grouping dummy variable (treat). The regression results are consistent with the benchmark model. In addition, interference from other potential policy factors may exist to cause differences in the productivity trends of processing trade and ordinary trade firms. We specifically used China's accession to the World Trade Organization (WTO) in 2001 as a potential policy shock. The time boundary for models (3) and (4) was changed to 2001, and the samples after 2004 are excluded. The interaction term is represented by $t r$. It can be seen that the regression result is not statistically significant. To further eliminate the interference of substantial policy factors, we randomly set the time dummy of 2005-06 to 1 . The interaction term is represented by $t d$, and the regression result is as model (5). As shown in model (6), the regression results did not pass the significance test. Therefore, we believe that the impact of other potential policies can be further excluded.

Table 8.5 Robustness test for pretreatment trend and other coexistent policies

\begin{tabular}{|c|c|c|c|c|c|c|}
\hline \multirow{2}{*}{ Variable } & (1) & (2) & (3) & (4) & (5) & (6) \\
\hline & TFP_OP & TFP_LP & TFP_OP & TFP_LP & TFP_OP & TFP_LP \\
\hline \multirow[t]{2}{*}{$t t$} & $-0.1170^{\star \star *}$ & $-0.1040^{\star \star \star}$ & & & & \\
\hline & $(0.0141)$ & $(0.0141)$ & & & & \\
\hline \multirow[t]{2}{*}{$t$} & $35.1890^{\star \star *}$ & $18.3270^{*}$ & & & & \\
\hline & (10.2110) & (10.2878) & & & & \\
\hline \multirow[t]{2}{*}{ ts } & $-0.0050^{\star *}$ & $-0.0060^{\star \star \star}$ & & & & \\
\hline & $(0.0020)$ & $(0.0021)$ & & & & \\
\hline \multirow[t]{2}{*}{ tr } & & & 0.0260 & 0.0280 & & \\
\hline & & & $(0.0175)$ & $(0.0175)$ & & \\
\hline \multirow[t]{2}{*}{$t d$} & & & & & 0.0140 & 0.0050 \\
\hline & & & & & $(0.0126)$ & $(0.0125)$ \\
\hline Observations & 13,5169 & 134,907 & 48,862 & 48,636 & 135,169 & 134,907 \\
\hline
\end{tabular}

*** $p<0.01$

** $p<0.05$

${ }^{*} p<0.1$

Notes: Regression equations include control variables regarding firm, region and industry. City, industry and time fixed effects have been controlled for unobserved variation.

Source: Authors' own estimation. 


\section{Further heterogeneity tests}

The distribution of China's processing trade between eastern and western regions and different types of enterprises is uneven. We further examine the different performance of the policy effects from the perspectives of region, enterprise and composition of processing trade.

Regarding the distribution of Chinese export companies, we make several assumptions. First, the productivity of firms in the eastern region is relatively higher than in other regions and most of the country's export firms are concentrated in the east. The firms in the eastern region are also more likely to become the focus of regulation, therefore policies may lower the average productivity of export firms in the eastern region and thereby reduce their overall level of efficiency. Second, the regression results in Table 8.1 show that the coefficient of foe is basically positive and the coefficient of soe is basically negative, indicating that the productivity of foreignfunded enterprises is relatively higher than that of state-owned and collective firms. At the same time, foreign-funded firms and joint ventures account for more than 80 per cent of the export sector, making them the potential focus of regulation. The effect generated by policies may therefore reduce the overall efficiency level by lowering the production efficiency of foreign-funded enterprises. From another perspective, the imported-material processing trade firms are characterised by having 'two ends outside', with both the import of raw materials and the export sales of products relying heavily on the international market. As such, the effect of domestic industrial policies could be relatively small. At the same time, ordinary trade firms are more likely to use domestic raw materials to replace imported raw materials under such policies, and as ordinary trade firms account for more than 95 per cent of processing trade, these may become an important target for regulation.

\section{Heterogeneity test of regions and trade patterns}

Economic development in China varies significantly by region. The eastern region is more developed and has a higher degree of industrial development than the others. Mature industries are faced with meeting the requirements of the transformation and upgrading policies and many labour-intensive and relatively mature industries have gradually relocated to the central and western regions. Foxconn, for instance, has invested in factories in Zhengzhou City in the central region and Chengdu City in the west. The regression results in Table 8.6 show that the net effect of these policies is not significant in the central and western regions, but has a significant, negative impact in the eastern region. This is because the eastern region is the main gathering area for processing trade, and the total export value of processing trade from the eastern region accounts for 98 per cent of the country's total processing exports. Although the policy proposes promoting the transfer of processing trade enterprises to the central and western regions, the eastern region retains certain geographical advantages and such transfers cannot be completed in one step. In addition, export 
enterprises in the eastern region face higher degrees of marketisation and have comparative advantages in location and transportation for processing trade. In the short term, transformation and upgrading policies may disrupt the original resource allocation conditions. The transfer of processing trade enterprises from the east to the central and western regions has resulted in a reduction in labour and land costs, but in the short term, this cannot compensate for the comparative advantages of the eastern region, thereby reducing the production efficiency of processing trade enterprises. As an extension, the central and western regions - as the main destinations for the transfer of processing trade-should actively undertake the transfer of enterprises and establish corresponding support facilities, as well as accept enterprises with higher development levels and higher production efficiencies, thereby improving the region's overall level of production efficiency.

Table 8.6 Heterogeneity test with location

\begin{tabular}{|l|c|c|c|c|c|c|c|c|}
\hline \multirow{4}{*}{ Variable } & \multicolumn{9}{|c|}{$(\mathbf{1 )}$} & $\mathbf{( 2 )}$ & $\mathbf{( 3 )}$ & $\mathbf{( 4 )}$ & $\mathbf{( 1 )}$ & $\mathbf{( 2 )}$ & $\mathbf{( 3 )}$ & (4) \\
\cline { 2 - 9 } & \multicolumn{3}{|c|}{ Eastern region } & $\begin{array}{c}\text { Central } \\
\text { and } \\
\text { western } \\
\text { regions }\end{array}$ & $\begin{array}{c}\text { Processing trade } \\
\text { with imported } \\
\text { materials }\end{array}$ & $\begin{array}{c}\text { Processing trade } \\
\text { with supplied } \\
\text { materials }\end{array}$ \\
\cline { 2 - 10 } & TFP_OP & TFP_LP & TFP_OP & TFP_LP & TFP_OP & TFP_LP & TFP_OP & TFP_LP \\
\hline \multirow{2}{*}{$t t$} & $-0.1010^{\star \star \star}$ & $-0.0890^{\star \star \star}$ & -0.0230 & -0.0210 & $-0.1280^{\star \star \star}$ & $-0.1130^{\star \star \star}$ & -0.0580 & -0.0540 \\
\cline { 2 - 10 } & $(0.0151)$ & $(0.0151)$ & $(0.0822)$ & $(0.0843)$ & $(0.0152)$ & $(0.0152)$ & $(0.0390)$ & $(0.0398)$ \\
\hline Observations & 119,443 & 119,342 & 15,726 & 15,565 & 130,634 & 130,377 & 110,423 & 110,181 \\
\hline
\end{tabular}

*** $p<0.01$

** $p<0.05$

${ }^{*} p<0.1$

Notes: Regression equations include control variables regarding firm, region and industry. City, industry and time fixed effects have been controlled for unobserved variation.

Source: Authors' own estimation.

The proportion of processing trade with supplied materials is below 5 per cent of total exports and this proportion has been on a downward trend since 2000, indicating that the importance of processing trade is also declining. It can be seen in Table 8.7 that the interaction term coefficient is significantly negative, which is consistent with the benchmark model. The interaction term coefficient in processing trade with supplied materials is negative, but not significant. The export value of processing trade with imported materials accounts for more than 95 per cent of all processing trade. Policies for the transformation and upgrading of processing trade are aimed at domestic firms, so firms engaged in processing trade with imported materials may be directly affected. Processing trade with supplied materials has the typical features of 'two ends outside'. In this case, the firm imports its raw materials from abroad, following which almost all of its product is sold on foreign markets. These firms maintain close ties with the country in which their parent company is located. Hence, firms engaged in processing trade with supplied materials are more 
susceptible to international market fluctuations and are relatively less affected by domestic industrial policies. In addition, firms engaged in processing trade with supplied materials are concentrated in simple processing and assembly businesses, most of which are labour-intensive industries characterised by low levels of production technology or low production efficiencies; as such, the crowding-out effects of these policies are likely to be negligible.

\section{Heterogeneity test regarding the status of firms}

The export value of joint ventures and foreign-funded enterprises accounts for more than 90 per cent of processing trade. The focus of policies for processing trade transformation and upgrading is on increasing the export proportion of private firms. As such, it is necessary to reconfirm the status of the sampled firms. The statistics indicate that the export value of joint-venture (cooperative) enterprises and wholly foreign-owned firms accounts for about 80 per cent of the total export value, although this declined in 2006. Meanwhile, the export value of private and state-owned firms has not changed much. We identify firms' status by the sixth digit of the firm customs code, employing the same grouping method previously stated. We divide the samples into four groups: private enterprises, state-owned enterprises, joint ventures and foreign-funded enterprises. The specifications of the treatment and control groups remain consistent. The regression results are displayed in Table 8.8. The results show that the interaction term coefficients for the joint ventures and foreign-funded enterprises are significantly negative, indicating that the net effect of the policy is significantly negative. Meanwhile, the interaction term coefficient for the private and state-owned enterprises is not significant.

Table 8.7 Heterogeneity test regarding firm status

\begin{tabular}{|l|c|c|c|c|c|c|c|c|}
\hline \multirow{4}{*}{ Variable } & $\mathbf{( 1 )}$ & $\mathbf{( 2 )}$ & $\mathbf{( 3 )}$ & $\mathbf{( 4 )}$ & $\mathbf{( 5 )}$ & $\mathbf{( 6 )}$ & $\mathbf{( 7 )}$ & (8) \\
\cline { 2 - 9 } & \multicolumn{2}{|c|}{ Private firms } & \multicolumn{2}{|c|}{ soe } & \multicolumn{2}{c|}{ Joint ventures } & \multicolumn{2}{c|}{ foe } \\
\cline { 2 - 9 } & TFP_OP & TFP_LP & TFP_OP & TFP_LP & TFP_OP & TFP_LP & TFP_OP & TFP_LP \\
\hline \multirow{2}{*}{$t t$} & -0.0230 & -0.0230 & 0.0180 & 0.0060 & $-0.0820^{\star \star \star}$ & $-0.0760^{\star \star \star}$ & $-0.0910^{\star \star \star}$ & $-0.0810^{\star \star \star}$ \\
\cline { 2 - 9 } & $(0.0925)$ & $(0.0907)$ & $(0.0859)$ & $(0.0867)$ & $(0.0229)$ & $(0.0229)$ & $(0.0260)$ & $(0.0262)$ \\
\hline \multirow{2}{*}{ Observations } & 36,860 & 36,841 & 21,365 & 21,260 & 41,648 & 41,566 & 35,296 & 35,240 \\
\hline
\end{tabular}

*** $p<0.01$

** $\mathrm{p}<0.05$

${ }^{*} p<0.1$

Notes: Regression equations include control variables regarding firm, region and industry. City, industry and time fixed effects have been controlled for unobserved variation.

Source: Authors' own estimation.

The export value of foreign-funded enterprises (including joint ventures) has fluctuated greatly since 2005, while the export value of private and state-owned enterprises has not changed much in the same period, indicating that foreignfunded enterprises have experienced greater policy impacts. Private and state-owned 
enterprises account for a relatively small proportion of exports, while the impacts of transformation and upgrading policies are not obvious. At the same time, foreignfunded enterprises possess comparative advantages in terms of developing processing trade-for instance, compared with private and state-owned enterprises, foreignfunded firms are more familiar with the international market; moreover, they may receive management and even technical support from their parent company, as well as relatively mature development experience and an established international customer network. Private and state-owned enterprises, on the other hand, are at a relative disadvantage in the realm of international competition; as such, supportive policies may cause distortions and the misallocation of resources in the short term, thereby reducing firm productivity.

In addition, foreign-funded enterprises engaged in processing trade have the potential to generate more significant technological learning effects for the country (Kandogan 2003). However, one of the goals of the transformation and upgrading policies is to increase the diversification of business entities and increase the proportion of private and state-owned firms' exports as a share of total trade. Because of this, the direct impact of policies may serve to inhibit the transformation of foreign-funded enterprises' technological learning effects, thereby reducing their production efficiency. Private and state-owned enterprises have different priorities. In 1994, China promulgated the Foreign Trade Law to deepen the reform of the foreign trade system and gradually transfer foreign trade management rights from state-owned enterprises to private enterprises (Ping and Huang 2018).

\section{Heterogeneity tests regarding region, trade mode and enterprise status}

Region, trade mode and enterprise status are factors that cause variance in the net effectiveness of policies. The net effect of the policies is significantly negative when focusing on samples located in eastern China, which are primarily engaged in processing trade with imported materials and possess joint-venture or foreignfunded firm status. We will take these factors into further consideration and finish the heterogeneity tests.

We first consider the factors of region and trade mode, with the regression results displayed in Table 8.8. It can be seen from the table that the interaction term coefficient in the case of firms engaged in processing trade with imported materials in the eastern region is significantly negative, while the other results do not pass the significance test. It can be seen that the eastern region and processing trade with imported materials are the main factors influencing the policies' negative net effects.

On this basis, we retain the sample of firms in processing trade with imported materials in the eastern region to further investigate the differences in the status of firms. The results are shown in Table 8.9. The results are consistent with previous 
regressions: the interaction term coefficients of joint ventures and foreign-funded firms are significantly negative and the interaction term coefficients of private and state-owned enterprises are positive, failing to pass the significance test. The previous analysis shows that joint ventures and foreign-funded enterprises account for more than 80 per cent of processing trade exports and they are the key targets of the transformation and upgrading policies.

Table 8.8 Heterogeneity test by region and trade mode

\begin{tabular}{|c|c|c|c|c|c|c|c|c|}
\hline \multirow{4}{*}{ Variable } & (1) & (2) & (3) & (4) & (5) & (6) & (7) & (8) \\
\hline & \multicolumn{4}{|c|}{$\begin{array}{l}\text { Processing trade with } \\
\text { imported materials }\end{array}$} & \multicolumn{4}{|c|}{$\begin{array}{l}\text { Processing trade with } \\
\text { supplied materials }\end{array}$} \\
\hline & \multicolumn{2}{|c|}{ Eastern } & \multicolumn{2}{|c|}{$\begin{array}{l}\text { Central and } \\
\text { western }\end{array}$} & \multicolumn{2}{|c|}{ Eastern } & \multicolumn{2}{|c|}{$\begin{array}{l}\text { Central and } \\
\text { western }\end{array}$} \\
\hline & TFP_OP & TFP_LP & TFP_OP & TFP_LP & TFP_OP & TFP_LP & TFP_OP & TFP_LP \\
\hline \multirow[t]{2}{*}{$t t$} & $-0.1140^{\star \star \star}$ & $-0.1000^{\star \star \star}$ & 0.1520 & 0.1480 & -0.0300 & -0.0270 & -0.2960 & -0.2930 \\
\hline & (0.0163) & $(0.0163)$ & $(0.1066)$ & $(0.1088)$ & $(0.0306)$ & (0.0308) & $(0.1251)$ & $(0.1273)$ \\
\hline Observations & 115,134 & 115,034 & 15,500 & 15,343 & 95,114 & 95,025 & 15,309 & 15,156 \\
\hline
\end{tabular}

*** $\mathrm{p}<0.01$

** $\mathrm{p}<0.05$

${ }^{*} p<0.1$

Notes: Regression equations include control variables regarding firm, region and industry. City, industry and time fixed effects have been controlled for unobserved variation.

Source: Authors' own estimation.

We argue, however, that the motivation for foreign-funded enterprises in processing trade to upgrade and improve their production efficiency may not be great, as the main purpose of these enterprises is to seek low-cost labour to reduce production costs and obtain higher profits. After being impacted by external policies, they have the flexibility to adjust their production strategies. Judging from the fact that a large number of foreign-funded firms have relocated their production bases to Southeast Asian countries in recent years, we believe foreign-funded enterprises have more flexibility in lowering costs. It can be seen from the regression results that the regression coefficients from model (1) to model (4) are positive but not significant, indicating that the crowding-out effect generated by these policies on private and state-owned enterprises is negligible. This is in line with the fact that the transformation and upgrading policies were intended to support private firms. Extending this further, we believe that the main focus of these transformation and upgrading policies should still be placed on private and state-owned enterprises. However, given that foreign-funded enterprises have suffered relatively greater policy crowding-out effects, appropriate subsidies could be provided during the initial stage of policy implementation to reduce their short-term negative impacts. 
Table 8.9 Heterogeneity by firm status

\begin{tabular}{|c|c|c|c|c|c|c|c|c|}
\hline \multirow{3}{*}{ Variable } & (1) & (2) & (3) & (4) & (5) & (6) & (7) & (8) \\
\hline & \multicolumn{2}{|c|}{ Private firms } & \multicolumn{2}{|c|}{ soe } & \multicolumn{2}{|c|}{ Joint ventures } & \multicolumn{2}{|c|}{ foe } \\
\hline & TFP_OP & TFP_LP & TFP_OP & TFP_LP & TFP_OP & TFP_LP & TFP_OP & TFP_LP \\
\hline \multirow[t]{2}{*}{ tt } & 0.1130 & 0.1100 & 0.1230 & 0.1150 & $-0.0880^{\star \star \star}$ & $-0.0800^{\star \star \star}$ & $-0.1040^{\star \star \star}$ & $-0.0940^{\star \star \star}$ \\
\hline & $(0.1126)$ & $(0.1098)$ & $(0.1029)$ & $(0.1028)$ & $(0.0253)$ & $(0.0253)$ & $(0.0285)$ & $(0.0286)$ \\
\hline Observations & 31,983 & 31,970 & 14,934 & 14,911 & 36,697 & 36,671 & 31,520 & 31,482 \\
\hline
\end{tabular}

*** $p<0.01$

** $p<0.05$

${ }^{*} p<0.1$

Notes: Regression equations include control variables regarding firm, region and industry. City, industry and time fixed effects have been controlled for unobserved variation.

Source: Authors' own estimation.

In summary, transformation and upgrading policies have caused a decline in the productivity of processing trade firms, on average. We find the constructed DID model to be robust under different assumptions. Moreover, we considered the development trends of regions and industries to deal with the endogeneity problem and excluded the influence of other potential policy factors through a parallel trend test.

\section{Conclusion}

Since the implementation of the processing trade transformation and upgrading strategy in 2003, the proportion of China's processing trade in total exports has continued to decline, but the product structure has tended to improve in terms of technological content. This study uses the DID method to test the impact of processing trade transformation and upgrading policies on enterprise productivity. The study shows that such policies will reduce industry's average productivity and lead to resource misallocation.

Specifically, our empirical tests found that: first, the net effect of the transformation and upgrading policies on productivity has been negative, which means that, from the perspective of resource allocation efficiency, the policies have incurred distortions, indicating that, although the policy goal may have been achieved, it has been at the expense of efficiency. Innovation and profit factors may be microchannels through which policies affect enterprise productivity. The transformation and upgrading policies for processing trade reduce the level of innovation and profitability of enterprises, but enterprise innovation and profitability can increase enterprise productivity. Second, the misallocation of resources is concentrated in China's eastern region, while foreign-funded enterprises and firms engaged in processing trade with imported materials have been the most negatively affected by the policies. 
China's processing trade is concentrated in the eastern region and is primarily labour intensive. Most processing trade companies have relatively high production efficiency in labour-intensive industries - a fact that is most obvious among foreignfunded companies. Additionally, labour-intensive processing trade enterprises are among those most negatively affected by the adoption of transformation and upgrading policies, leading to a loss of productivity, on average. Industrial policy must be efficiency-oriented or it will inevitably cause new distortions.

\section{References}

Alder, S., Shao, L. and Zilibotti, F. (2016), Economic reforms and industrial policy in a panel of Chinese cities, Journal of Economic Growth 21(4): 304-49. doi.org/10.1007/ s10887-016-9131-x.

Blonigen, B.A. (2016), Industrial policy and downstream export performance, The Economic Journal 126(595): 1635-59. doi.org/10.1111/ecoj.12223.

Brandt, L., Van Biesebroeck, J. and Zhang, Y. (2012), Creative accounting or creative destruction? Firm-level productivity growth in Chinese manufacturing, Journal of Development Economics 97(2): 339-51. doi.org/10.1016/j.jdeveco.2011.02.002.

Dai, M., Yu, M. and Maitra, M. (2014), The mystery of the productivity of Chinese export companies: The role of processing trade, [In Chinese], Economics (Quarterly) 13(2): 675-98.

Ellison, G. and Glaeser, E.L. (1999), The geographic concentration of industry: Does natural advantage explain agglomeration?, The American Economic Review 89(2): 311-16. doi.org/ 10.1257/aer.89.2.311.

Fan, G., Wang, X. and Ma, G. (2011), Contribution of China's marketization process to economic growth, [In Chinese], Economic Research (9): 4-16.

Feenstra, R.C. and Hanson, G.H. (1995), Foreign investment, outsourcing and relative wages, NBER Working Papers 5121, Cambridge, MA: National Bureau of Economic Research. doi.org/10.3386/w5121.

Gan, C., Zheng, R. and Yu, D. (2011), The impact of China's industrial structure changes on economic growth and volatility, [In Chinese], Economic Research (5): 4-16, 31.

Ge, W. (1999), The Dynamics of Export-Processing Zones, Geneva: United Nations Conference on Trade and Development.

Jayachandran, S., Lleras-Muney, A. and Smith, K.V. (2010), Modern medicine and the twentieth century decline in mortality: Evidence on the impact of sulfa drugs, American Economic Journal: Applied Economics 2(2): 118-46. doi.org/10.1257/app.2.2.118.

Kandogan, Y. (2003), Intra-industry trade of transition countries: Trends and determinants, Emerging Markets Review 4(3): 273-86. doi.org/10.1016/S1566-0141(03)00040-2. 
Lall, S., Weiss, J. and Zhang, J. (2006), The 'sophistication' of exports: A new trade measure, World Development 34(2): 222-37.

Levinsohn, J. and Petrin, A. (2003), Estimating production functions using inputs to control for unobservables, The Review of Economic Studies 70(2): 317-41. doi.org/10.1111/1467937X.00246.

Lu, J., Lu, Y. and Tao, Z. (2010), Exporting behavior of foreign affiliates: Theory and evidence, Journal of International Economics 81(2): 197-205. doi.org/10.1016/j.jinteco. 2010.03.002.

Nie, H., Jiang, T. and Yang, R. (2012), The current status and potential problems of the use of Chinese industrial enterprise database, [In Chinese], World Economy (5): 142-58.

Olley, S. and Pakes, A. (1996), The dynamics of productivity in the telecommunications equipment industry, Econometrica 64(6): 1263-97. doi.org/10.2307/2171831.

Ping, X. and Huang, X. (2018), Research on the heterogeneity of different ownership enterprises in various markets, [In Chinese], Economic Aspect (2): 35-48.

Shang, X. and Zhu, S. (2017), Analysis on the effect of agricultural land circulation subsidy policy: Based on crowding-out effect, government rent creation and target deviation perspective, [In Chinese], China Rural Observation (6): 43-56.

Shi, B. and Zhang, Y. (2016), Trade liberalization and the upgrade of imported intermediate quality of Chinese enterprises, [In Chinese], Quantitative Economics and Technical Economic Research (9): 3-21.

The State Council of the People's Republic of China (2000), Interim Measures of the Customs of the People's Republic of China on the Supervision of Export Processing Zones. General Administration of the People's Republic of China.

Tian, W. and Yu, M. (2012), Enterprise productivity and 'going global' foreign direct investment: An empirical study based on enterprise level data, [In Chinese], Economics (Quarterly) 11(2): 383-408. 
This text is taken from China's Challenges in Moving towards a High-income Economy, edited by Ligang Song and Yixiao Zhou, published 2021 by ANU Press, The Australian National University, Canberra, Australia.

doi.org/10.22459/CCMTHE.2021.08 